\title{
Efektywność rozwoju przedsiębiorstw produkcyjnych wysokiej techniki w Polsce
}

W epoce kształtowania się społeczeństwa informacyjnego wzrost gospodarczy staje się coraz bardziej uzależniony od produkcji, dystrybucji i wykorzystania wiedzy (patrz np. Woroniecki 2003, Chojnicki, Czyż 2006, Kobyłko, Morawski 2006, Porter 2006, Przybyszewski 2007, Welfe 2007, Wieloński 2007, Grudzewski, Hejduk 2008, Zioło 2008, 2009, Świdurska 2009). Uzależnienie rozwoju przedsiębiorstwa od pozyskiwania i wykorzystywania wiedzy praktycznie w każdym aspekcie jego działalności, nasilające się procesy integracyjne i globalizacyjne, ciągły wzrost turbulencji otoczenia, rosnące wymagania klientów wymuszają na przedsiębiorstwach podejmowanie działań zwiększających efektywność funkcjonowania i doskonalenie procesów zarządzania. Współczesne przedsiębiorstwo, chcąc przetrwać na rynku i dostosować się do mających miejsce ciągłych zmian w otoczeniu, powinno charakteryzować się wysokim poziomem elastyczności (zwinności, ruchliwości, zdolności do utrzymania stanu równowagi) i w sposób niemal natychmiastowy dopasowywać swoje funkcjonowanie do otoczenia. Stosując procesy organizacyjnego uczenia się, przedsiębiorstwa podwyższają swój poziom adaptacyjności i dążą do uzyskania zdolności proaktywnego wykorzystania okazji pojawiających się w otoczeniu, a koncentrując się na swoich szczególnych zdolnościach i pozbywając się wszelkich działalności „ubocznych” przez dywestycje i outsourcing, uzupełniają swoje możliwości, wykorzystując zasoby zewnętrzne (Mikuła, Pietruszka-Ortyl, Potocki 2007).

W ramach teorii organizacji i zarządzania wypracowano kilka modeli organizacji zdolnych do sprawnego działania w warunkach gospodarki opartej na wiedzy. Nie przeprowadzając analizy tych koncepcji - co wykracza poza ramy niniejszego opracowania - należy zaznaczyć, że założenia stanowiące podstawę modeli organizacji działających w warunkach wysokiej turbulencji otoczenia zostały przedstawione np. w pracach Senge (1998), Stryjakiewicza (1999), Grudzewskiego, Hejduk (2000), Krupskiego (2005), Mikuły (2005, 2006), Perechudy (2005), Portera (2006), Mikuły, Pietruszki-Ortyl, Potockiego (2007).

Analizę działalności przedsiębiorstw w świetle założeń tych koncepcji traktuje się jako wyznacznik kontynuacji badań nad rozwojem przemysłu wysokiej techniki w Polsce. Cel prezentowanego opracowania ukierunkowano natomiast na ogólną analizę i ocenę efektywności rozwoju przedsiębiorstw reprezentujących sekcję produkcyjną wysokiej techniki. Podstawową grupę materiałów źródłowych stanowią dane dotyczące firm, które 
w latach 2000-2008 zostały ujęte na „Liście 500” największych przedsiębiorstw w Polsce1. Charakterystykę działalności przedsiębiorstw przeprowadzono za pomocą pięciu wskaźników ekonomicznych: przychodów ze sprzedaży, wartości zysku/straty, nakładów inwestycyjnych, zatrudnienia i udziału eksportu. Należy jednak zwrócić uwagę, że zakres charakterystyki przedsiębiorstw jest ograniczony, ponieważ determinują go niekompletne informacje o wynikach działalności ekonomicznej firm. Ponadto na „Listach 500” brakuje wielu przedsiębiorstw, które odmówiły podania swoich danych.

Polska charakteryzuje się nadal bardzo niskim udziałem produktów wysokiej techniki W ogólnej wartości sprzedaży. W polskiej gospodarce luka technologiczna nadal powiększa się. Świadczą o tym m.in.: 1) obniżenie poziomu zdolności konkurencyjnej wielu polskich produktów na rynku światowym, 2) wyraźna przewaga konkurencyjna wyrobów zagranicznych, pochodzących niekiedy z krajów o co najwyżej średnim poziomie rozwoju, 3) zmniejszenie produktywności wielu stosowanych w polskim przemyśle technologii zagranicznych, 4) nadmierne zużycie materiałów, surowców i energii, 5) nadmierna różnorodność wytwarzanych wyrobów w jednym przedsiębiorstwie, co utrudnia specjalizację i redukcję kosztów jednostkowych (Grudzewski, Hejduk 2008, s. 48). Niezbędne jest globalne podejście do nadrobienia tego zapóźnienia, czemu sprzyja członkostwo w Unii Europejskiej, wsparcie z jej funduszy oraz otwarcie na gospodarkę światową.

Nawiązując do listy branż i produktów wysokiej techniki, ustalonej przez $\mathrm{OECD}^{2}$, udział tych branż w ogólnej wartości sprzedaży w $2006 \mathrm{r}$. wynosił niespełna 4,2\% ${ }^{3}$. W prezentowanym opracowaniu podstawę empirycznej charakterystyki przedsiębiorstw wysokiej techniki stanowi wykaz działów (branż) produkcyjnych wysokiej techniki według klasyfikacji PKD obowiązującej w 2006 r. (polskiej wersji klasyfikacji Unii Europejskiej NACE). Do przemysłu wysokiej techniki zalicza się (por. Chojnicki, Czyż 2006): produkcję chemikaliów (D24), produkcję maszyn i urządzeń (D29), produkcję maszyn biurowych i komputerów (D30), produkcję maszyn i aparatury elektrycznej (D31), produkcję sprzętu i urządzeń radiowych, telewizyjnych i telekomunikacyjnych (D32), produkcję instrumentów medycznych, precyzyjnych i optycznych, zegarów i zegarków (D33), produkcję pojazdów mechanicznych, przyczep i naczep (D34), produkcję pozostałego sprzętu transportowego (D35).

Jak wynika z danych udostępnionych przez GUS (tab. 1), spośród 2017 przedsiębiorstw produkcyjnych wysokiej techniki zarejestrowanych w 2007 r., w których liczba pracujących przekracza 49 osób, połowa prowadziła działalność na obszarze czterech województw: śląskiego (16,3\%), mazowieckiego (13,9\%), dolnośląskiego (11\%), wielkopolskiego $(10,6 \%)$. Co trzecie przedsiębiorstwo było zlokalizowane w ośrodku regionalnym. Na przykład w Warszawie prowadziło działalność 155 przedsiębiorstw, które stanowiły 55\% ogółu przedsiębiorstw produkcyjnych wysokiej techniki w województwie mazowieckim.

Analiza lokalizacji 76 firm ujętych na „Liście 500” największych przedsiębiorstw w Polsce w 2008 r. pozwala ustalić, że firmy te cechuje umiarkowany stopień koncentracji przestrzennej. Analizowane przedsiębiorstwa prowadzą działalność w 44 gminach w 12 wo-

\footnotetext{
1 „Listy 500” były publikowane na łamach dziennika „Rzeczpospolita” w latach 2001-2009. Lista przedstawia ranking największych firm przemysłowych i usługowych w Polsce według kryterium rocznego przychodu z działalności podstawowej firm.

${ }^{2}$ W tym ujęciu przemysł wysokiej techniki obejmuje branże: D30, D32, D33, produkcję wyrobów farmaceutycznych (24.4), produkcję statków powietrznych i kosmicznych (35.3).

${ }^{3}$ Dotyczy przedsiębiorstw o liczbie pracujących powyżej 9 osób (źródło: niepublikowane materiały statystyczne GUS).
} 
jewództwach (tab. 1). W województwie mazowieckim funkcjonuje co czwarte przedsiębiorstwo produkcyjne wysokiej techniki ujęte na „Liście 500” w 2008 r., przy czym 82\% firm zlokalizowanych jest w Warszawie (14 firm). Województwa: mazowieckie, śląskie, wielkopolskie i dolnośląskie koncentrują ok. 70\% ogółu firm z „Listy”. W dziewięciu ośrodkach regionalnych zlokalizowanych jest $42 \%$ firm. W układzie gmin - obok Warszawy - kolejne miejsca zajmują Poznań (6 firm) i Tychy (3).

Tab. 1. Liczba przedsiębiorstw produkcyjnych wysokiej techniki o liczbie pracujących powyżej 49 osób (stan w maju 2007 r.) i ujętych na „Liście 500” w 2008 r.

\begin{tabular}{|c|c|c|c|c|}
\hline \multirow[b]{2}{*}{ Województwa } & \multicolumn{2}{|c|}{ Liczba przedsiębiorstw } & \multirow{2}{*}{$\begin{array}{l}\text { Udział ośrodka } \\
\text { regionalnego } \\
\text { w liczbie } \\
\text { przedsiębiorstw }\end{array}$} & \multirow{2}{*}{$\begin{array}{c}\text { Liczba } \\
\text { przedsiębiorstw } \\
\text { ujętych na „Liście 500” } \\
\text { w } 2008 \mathrm{r} .\end{array}$} \\
\hline & ogółem & $\begin{array}{l}\text { w ośrodku } \\
\text { regionalnym }\end{array}$ & & \\
\hline dolnośląskie & 221 & 59 & 26,7 & 9 \\
\hline kujawsko-pomorskie & 106 & 44 & 41,5 & 6 \\
\hline lubelskie & 65 & 23 & 33,8 & 2 \\
\hline lubuskie & 46 & 19 & 41,3 & 0 \\
\hline łódzkie & 133 & 62 & 46,6 & 2 \\
\hline małopolskie & 147 & 66 & 44,2 & 3 \\
\hline mazowieckie & 280 & 155 & 55,4 & 18 \\
\hline opolskie & 53 & 11 & 20,8 & 0 \\
\hline podkarpackie & 100 & 9 & 9,0 & 5 \\
\hline podlaskie & 30 & 17 & 56,7 & 0 \\
\hline pomorskie & 148 & 49 & 33,1 & 4 \\
\hline śląskie & 328 & 25 & 7,6 & 14 \\
\hline świętokrzyskie & 38 & 13 & 34,2 & 1 \\
\hline warmińsko-mazurskie & 36 & 4 & 11,1 & 0 \\
\hline wielkopolskie & 213 & 55 & 25,8 & 10 \\
\hline zachodniopomorskie & 73 & 27 & 37,0 & 2 \\
\hline Polska & 2017 & 638 & 31,6 & 76 \\
\hline
\end{tabular}

Źródło: Niepublikowane materiały statystyczne GUS; „Lista 500 największych firm Rzeczpospolitej” 2008; obliczenia własne

W latach 2000-2005 liczba przedsiębiorstw produkcyjnych wysokiej techniki, ujętych na „Liście 500”, systematycznie rosła (z 69 do 90 firm - por. tab. 2), podczas gdy w okresie 2007-2008 nastąpił spadek liczby podmiotów (z 89 do 76). Wśród firm, które dzięki dynamice swoich obrotów zadebiutowały na „Liście” w 2008 r., zasadniczą rolę odegrały przedsiębiorstwa usługowe, wytwarzające znacznie większą wartość dodaną. 
Istotne zmiany nastąpiły w strukturze firm produkcyjnych wysokiej techniki (tab. 2). W efekcie dynamicznego rozwoju przedsiębiorstw specjalizujących się w produkcji pojazdów mechanicznych liczba firm na „Liście” zwiększyła się w latach 2000-2007 z 10 do 26 . W 2008 r. branża motoryzacyjna była reprezentowana przez 21 firm. Cztery z tych firm wygenerowały w 2008 r. przychody ze sprzedaży powyżej 3 mld zł ${ }^{4}$ (tab. 3). W uwzględnionym okresie zwiększyła się również liczba producentów maszyn i urządzeń (D29), natomiast zmniejszyła się liczba przedsiębiorstw zajmujących się produkcją maszyn i aparatury elektrycznej oraz sprzętu i urządzeń radiowych, telewizyjnych i telekomunikacyjnych.

Tab. 2. Liczba przedsiębiorstw produkcyjnych wysokiej techniki z „Listy 500” w latach 2000-2008

\begin{tabular}{|c|r|r|r|r|r|r|r|r|r|}
\hline PKD & 2000 & 2001 & 2002 & 2003 & 2004 & 2005 & 2006 & 2007 & 2008 \\
\hline 24 & 24 & 28 & 29 & 30 & 29 & 29 & 27 & 24 & 26 \\
\hline 29 & 10 & 9 & 7 & 8 & 12 & 12 & 13 & 18 & 15 \\
\hline 30 & 1 & 1 & 2 & 0 & 0 & 1 & 0 & 1 & 0 \\
\hline 31 & 12 & 10 & 11 & 11 & 12 & 11 & 12 & 9 & 7 \\
\hline 32 & 6 & 5 & 8 & 7 & 5 & 8 & 4 & 5 & 2 \\
\hline 33 & 1 & 1 & 0 & 0 & 0 & 0 & 0 & 1 & 0 \\
\hline 34 & 10 & 12 & 16 & 21 & 22 & 25 & 23 & 26 & 21 \\
\hline 35 & 5 & 5 & 4 & 4 & 3 & 4 & 4 & 5 & 5 \\
\hline Ogółem & 69 & 71 & 77 & 81 & 83 & 90 & 83 & 89 & 76 \\
\hline
\end{tabular}

Źródło: „Lista 500 największych firm Rzeczpospolitej” 2000-2008; obliczenia własne

Niewielkie znaczenie przedsiębiorstw produkcyjnych wysokiej techniki sensu stricto uległo więc dalszemu zmniejszeniu. W 2008 r. na „Liście 500” ujętych zostało tylko pięć tego typu przedsiębiorstw, tj. LG Electronics Mława Sp. z o.o., GlaxoSmithKline Pharmaceuticals SA w Poznaniu, Sharp Manufacturing Poland Sp. z o.o. w Warszawie, Polpharma SA w Starogardzie Gdańskim i ICN Polfa Rzeszów SA. W całym analizowanym okresie na „Liście 500” zostało ujętych 37 firm high-tech według definicji OECD, tj. 18 producentów wyrobów farmaceutycznych, 17 producentów sprzętu i urządzeń radiowych, telewizyjnych i telekomunikacyjnych, trzech producentów maszyn biurowych i komputerów oraz firmy Alcatel-Lucent Polska SA w Warszawie i WSK PZL Rzeszów SA. Na przykład reprezentant branży komputerowej - Optimus SA - w 2000 r. zajmował miejsce 180, a w $2002-478$. Podsumowanie działalności firmy, której największy akcjonariusz podjął w 2008 r. decyzję o poszukiwaniu bardziej rentownej dziedziny działalności, mogą stanowić wyniki finansowe za lata 2004-2007. W okresie tym nastąpił spadek przychodów netto ze sprzedaży o 50\%.

\footnotetext{
${ }^{4}$ Dokonując oceny „wielkości” przedsiębiorstw ujętych na „Liście 500” warto skonfrontować ich przychody ze sprzedaży z przychodami uzyskanymi przez firmy ujęte w rankingu 2000 największych przedsiębiorstw na świecie przygotowanym przez amerykański miesięcznik gospodarczy Forbes. Zajmujący pierwszą pozycję PKN Orlen SA, z przychodami wynoszącymi 79,5 mld zł, został sklasyfikowany na „Liście Forbesa” na 283 pozycji. W 2007 r. firma zajmowała jednak dopiero 387 miejsce. Przychody przedsiębiorstwa były niższe od przychodów firmy zajmującej pierwszą pozycję odpowiednio: 17- i 22-krotnie. Należy również zwrócić uwagę, że firma Volkswagen Group w Niemczech, zajmująca na „Liście 2000” w 2008 r. 12 pozycję, uzyskała 40-krotnie wyższe przychody w porównaniu z przychodami osiągniętymi przez firmy Volkswagen Poznań Sp. z o.o. i Volkswagen Motor Polska Sp. z o.o. w Polkowicach.
} 
Spadek zysku brutto ze sprzedaży kształtował się na poziomie 70\%, a strata netto w $2007 \mathrm{r}$. - na poziomie $22 \mathrm{mln}$ zł.

Tab. 3. Największe przedsiębiorstwa produkcyjne wysokiej techniki w Polsce w 2008 r.

(o przychodach ze sprzedaży powyżej $3 \mathrm{mld}$ zł)

\begin{tabular}{|c|l|r|r|c|}
\hline \multicolumn{1}{|c|}{ Nazwa przedsiębiorstwa } & PKD & $\begin{array}{c}\text { Przychody } \\
\text { ze sprzedaży } \\
\text { w mln zł }\end{array}$ & $\begin{array}{c}\text { Zysk/ } \\
\text { strata } \\
\text { w mln zł }\end{array}$ \\
\hline 8 & Fiat Auto Poland SA, Bielsko-Biała & 3410 & 15082,9 & 312,0 \\
\hline 23 & Volkswagen Poznań Sp. z o.o, Poznań & 3410 & 9919,2 & 347,9 \\
\hline 56 & LG Electronics Mława Sp. z o.o., Mława & 3230 & 4018,2 & 172,7 \\
\hline 61 & Fiat-GM Powertrain Polska Sp. z o.o., Bielsko-Biała & 3410 & 3857,3 & 197,5 \\
\hline 63 & Volkswagen Motor Polska Sp. z o.o., Polkowice & 3410 & 3796,3 & 74,4 \\
\hline 65 & Philips Lighting Poland SA, Piła & 3150 & 3760,9 & 75,0 \\
\hline 68 & GlaxoSmithKline Pharmaceuticals SA, Poznań & 2442 & 3457,9 & b.d. \\
\hline 69 & Grupa Magneti Marelli, Sosnowiec & 3430 & 3356,2 & 123,6 \\
\hline 73 & Boryszew SA, Sochaczew SG & 2466 & 3243,7 & $-167,4$ \\
\hline
\end{tabular}

Źródło: „Lista 500 największych firm Rzeczpospolitej” 2008

W latach 2000-2008 na „Liście 500” zostało ujętych 198 przedsiębiorstw reprezentujących sektor produkcyjny wysokiej techniki, przy czym stały podzbiór firm, stanowiący zakres dalszych badań, złożony jest z 15 firm (ryc. 1-3). Analizowane przedsiębiorstwa to głównie firmy prywatne, w większości (9 firm) własności zagranicznej. Są one zróżnicowane pod względem branży.

W zbiorze 15 firm znajdują się firmy o zróżnicowanej wielkości przychodów ze sprzedaży: w 2000 r. od 415,1 mln zł (Electrolux Poland Sp. z o.o., Warszawa) do 6,7 mld zł (Fiat Auto Poland SA, Bielsko-Biała), a w 2008 r. od 813,6 mln zł (Zakłady Chemiczne Zachem SA, Bydgoszcz) do 15,1 mld zł (Fiat Auto Poland SA). W 2000 r. z przychodami powyżej 1 mld było siedem firm, a w 2008 r. - 13 firm, w tym pięć z przychodami powyżej 3 mld zł. W uwzględnionym okresie trzy przedsiębiorstwa wykazały przynajmniej 5-krotny wzrost przychodów, tj. Electrolux Poland Sp. z o.o, BSH Sprzęt Gospodarstwa Domowego Sp. z o.o. i GlaxoSmithKline Pharmaceuticals SA. Tylko Zakłady Chemiczne Zachem SA nie zwiększyły swoich przychodów. Tempo wzrostu przychodów jest wysoce zróżnicowane, w szczególności w ostatnich latach badanego okresu (ryc. 1-3).

Spośród 14 firm wykazujących wzrost przychodów tylko sześć firm należy do grupy firm awansujących na „Liście 500” w latach 2000-2008. Przedsiębiorstwa wykazujące ponad 5-krotny wzrost przychodów awansowały o ponad 100 miejsc: GlaxoSmithKline Pharmaceuticals SA ze 199 na 68 miejsce, BSH Sprzęt Gospodarstwa Domowego Sp. z o.o. - z 251 na 101, a Electrolux Poland Sp. z o.o. - z 289 na 107 pozycję. Zakres przesunięć ujemnych jest znacznie mniejszy od zakresu przesunięć dodatnich. Swoją pozycję w największym stopniu obniżyła firma Amica Wronki SA (ze 139 na 221 pozycję). 
$\mathrm{mln} z \nmid$

Przychody ze sprzedaży

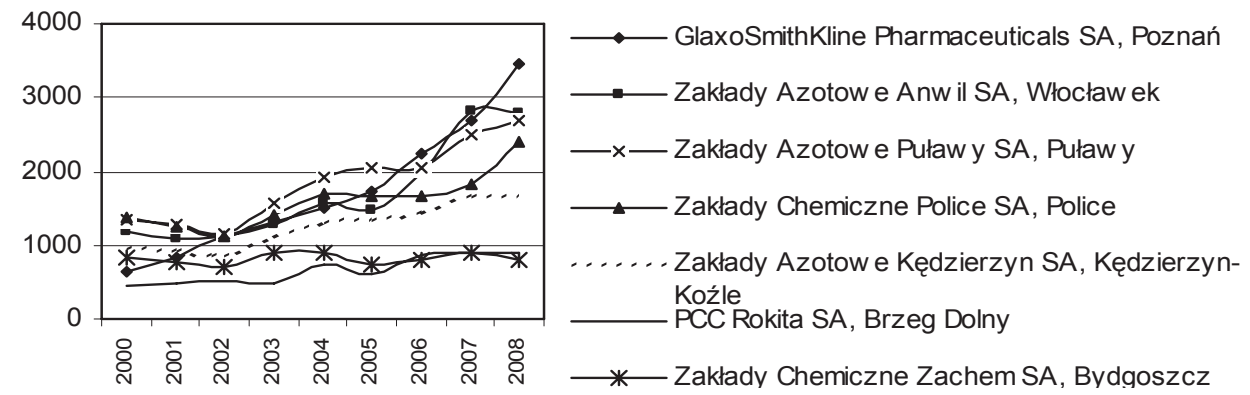

mln zł Wynik finansow y netto

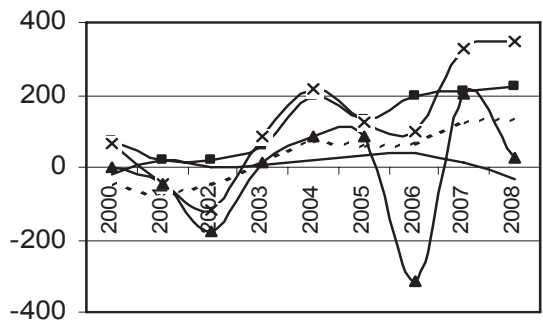

Zatrudnienie

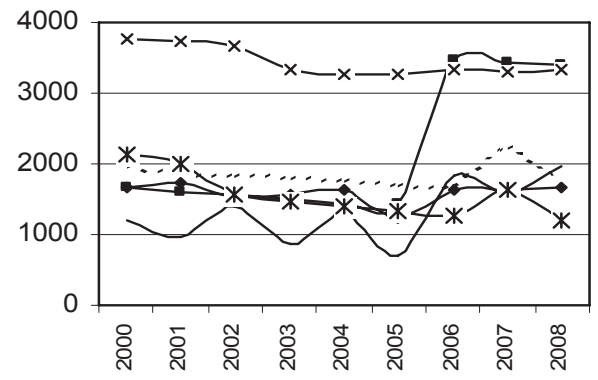

Ryc. 1. Rozwój przedsiębiorstw produkcyjnych wysokiej techniki (D24) w latach 2000-2008 w świetle podstawowych wskaźników ekonomicznych

Źródło: „Lista 500 największych firm Rzeczpospolitej” 2001-2008; opracowanie własne

Zyskowność przedsiębiorstw w ostatnich latach badanego okresu wykazała na ogół tendencję spadkową. Tylko producenci nawozów azotowych uzyskali w 2008 r. zyski kształtujące się na poziomie wyższym niż w poprzednich latach (ryc. 1). Największy spadek zyskowności dotyczy producentów maszyn i urządzeń (ryc. 2). Wyniki finansowe firm motoryzacyjnych, prowadzących działalność w otoczeniu stwarzającym szczególnie wiele zagrożeń, cechuje w ostatnich latach względna stabilizacja. Wyjątkiem jest firma Volkswagen Poznań Sp. z o.o. (ryc. 3).

Kształtujące się na niższym poziomie wyniki finansowe przedsiębiorstw w $2008 \mathrm{r}$. w porównaniu z 2007 r. nie są na ogół uwarunkowane wzrostem nakładów inwestycyjnych (tab. 4). Należy zwrócić uwagę, że wykazujące wzrost zysku Zakłady Azotowe w Kędzierzynie-Koźlu, Włocławku i Puławach wyróżniają się wzrostem nakładów inwestycyjnych w tym okresie odpowiednio: 2,7-, 2,2- i 1,2-krotnym. Wyraźny spadek nakładów inwestycyjnych wystąpił w firmie Fiat Auto Poland SA - o 42\%. Pod względem wielkości nakładów inwestycyjnych w całym analizowanym okresie dominowały firmy motoryzacyjne. Na przykład średnia roczna wartość inwestycji w firmie Fiat Auto Poland SA wynosiła 359 mln zł, a w firmie Volkswagen Poznań Sp. z o.o. - 312 mln zł. Wartość wskaźnika poniżej $50 \mathrm{mln}$ zł wykazały: Electrolux Poland $(9,8 \mathrm{mln})$, Volvo Polska Sp. z o.o. 
(22,3 mln), Zakłady Azotowe Kędzierzyn SA (29,9 mln), Amica Wronki SA (30,6 mln), Zakłady Chemiczne Zachem SA (37,7 mln).

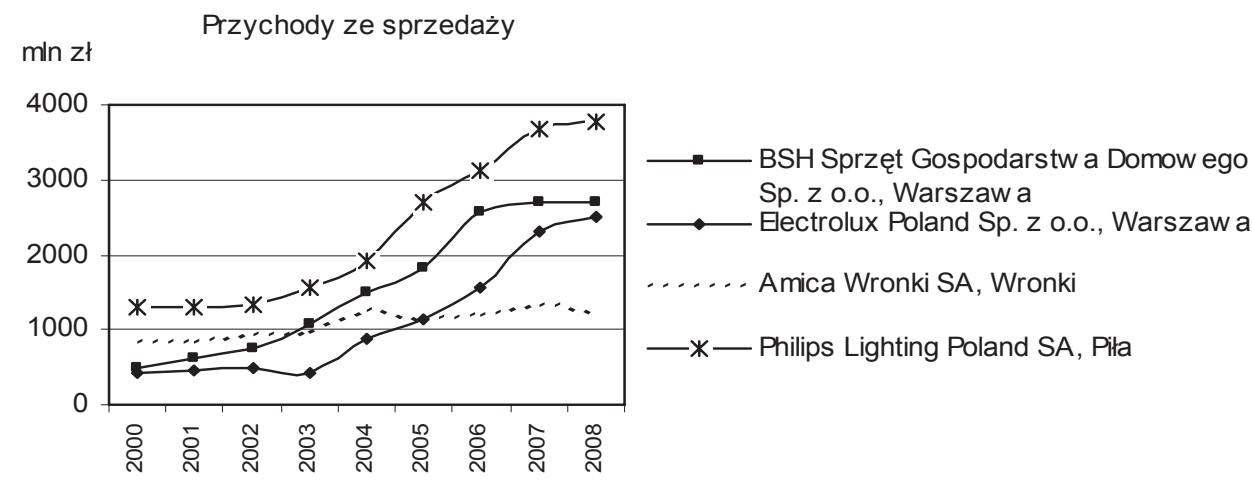

Zatrudnienie
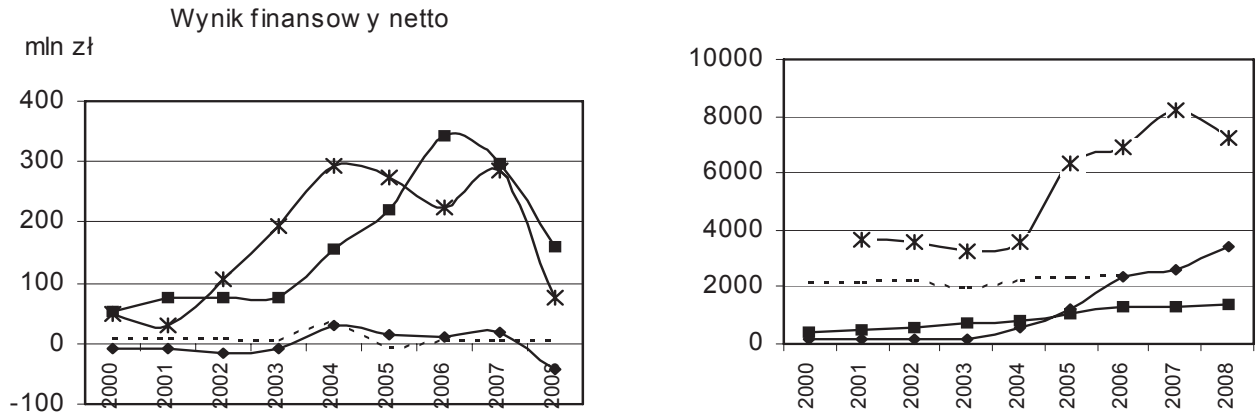

Ryc. 2. Rozwój przedsiębiorstw produkcyjnych wysokiej techniki (D29, D31)

w latach 2000-2008 w świetle podstawowych wskaźników ekonomicznych

Źródło: „Lista 500 największych firm Rzeczpospolitej” 2000-2008; opracowanie własne

Tab. 4. Nakłady inwestycyjne w przedsiębiorstwach produkcyjnych wysokiej techniki w latach 2000-2008 (w mln zł)

\begin{tabular}{|c|r|r|r|r|r|r|r|r|r|}
\hline Nr firmy & 2000 & 2001 & 2002 & 2003 & 2004 & 2005 & 2006 & 2007 & 2008 \\
\hline 1 & 184,1 & 193,7 & 37,0 & 36,7 & 91,5 & 270,4 & 230,9 & 117,1 & 255,6 \\
\hline 2 & 206,6 & 62,4 & 75,1 & 245,6 & 76,2 & 47,4 & 88,3 & 107,5 & 133,0 \\
\hline 3 & 10,1 & 9,8 & 18,2 & 14,4 & 25,7 & 64,6 & 82,6 & 207,2 & 266,5 \\
\hline 4 & 24,7 & 12,6 & 130,5 & 24,4 & 4,8 & 1,6 & 1,0 & 28,4 & 110,9 \\
\hline 5 & 8,4 & 9,2 & 17,9 & 10,8 & 20,5 & 18,3 & 34,4 & 40,9 & 109,3 \\
\hline 6 & 9,1 & 29,2 & 46,6 & 23,0 & 169,1 & 74,6 & 82,4 & 68,7 & 64,5 \\
\hline 7 & 3,1 & 2,2 & 1,6 & 2,9 & 52,6 & b.d. & 2,5 & 8,1 & 4,6 \\
\hline
\end{tabular}




\begin{tabular}{|c|c|r|r|r|r|r|r|r|r|}
\hline 8 & 15,6 & 21,8 & 26,7 & 6,7 & 25,4 & 56,6 & 34,2 & 47,2 & 40,7 \\
\hline 9 & b.d. & 0,7 & 38,7 & 75,1 & 95,6 & 182,2 & 197,8 & 239,5 & 173,0 \\
\hline 10 & 85,3 & 168,0 & 399,0 & 607,7 & 167,7 & 96,4 & 182,2 & 962,8 & 560,0 \\
\hline 11 & 204,0 & 430,9 & 517,0 & 784,1 & 201,9 & 104,5 & 157,4 & 157,2 & 251,8 \\
\hline 12 & 50,1 & 147,5 & 337,0 & 62,6 & 40,0 & 35,7 & 28,7 & 118,2 & 123,0 \\
\hline 13 & 48,2 & 14,5 & 16,2 & 12,4 & 6,5 & 18,2 & b.d. & 47,8 & 37,3 \\
\hline
\end{tabular}

1 - Zakłady Azotowe Anwil SA, Włocławek

2 - Zakłady Azotowe Puławy SA, Puławy

3 - PCC Rokita SA, Brzeg Dolny

4 - Zakłady Chemiczne Zachem SA, Bydgoszcz

5 - Zakłady Azotowe Kędzierzyn SA, Kędzierzyn-Koźle

6 - BSH Sprzęt Gospodarstwa Domowego Sp. z o.o., Warszawa

7 - Electrolux Poland Sp. z o.o., Warszawa

8 - Amica Wronki SA, Wronki

9 - Philips Lighting Poland SA, Piła

10 - Fiat Auto Poland SA, Bielsko-Biała

11 - Volkswagen Poznań Sp. z o.o, Poznań

12 - Volkswagen Motor Polska Sp. z o.o., Polkowice

13 - Volvo Polska Sp. z o.o., Wrocław

Źródło: „Lista 500 największych firm Rzeczpospolitej” 2000-2008

Na podstawie dostępnych danych dotyczących zatrudnienia dla 14 firm można ustalić, że w latach 2000-2008 w 10 przedsiębiorstwach wystapił wzrost zatrudnienia. Najwyższy wskaźnik wzrostu zatrudnienia wykazała firma Electrolux Poland Sp. z o.o. (22-krotny wzrost - o 3273 osoby), natomiast najniższy wskaźnik spadku zatrudnienia - Zakłady Chemiczne Zachem SA (o 44\%, tj. 936 osób). Najwięcej nowych pracowników zatrudniły firmy motoryzacyjne (Volkswagen Poznań Sp. z o.o. - 3536 osób, Volvo Polska Sp. z o.o. - 1532 osoby, Fiat Auto Poland SA - 1161 osób, Volkswagen Motor Polska Sp. z o.o. - 401 osób). W kontekście zmian na krajowym rynku pracy należy zaznaczyć, że rola badanych przedsiębiorstw w tworzeniu popytu na pracę nie uległa zasadniczemu ograniczeniu. W 2008 r. firmy Fiat Auto Poland SA, PCC Rokita SA oraz Electrolux Poland Sp. z o.o. zwiększyły zatrudnienie o przynajmniej 30\%. Na przeciwnym biegunie znalazły się Zakłady Chemiczne Zachem SA (spadek zatrudnienia o 23\%), Zakłady Azotowe Kędzierzyn SA (o 23\%) oraz firma Philips Lighting Poland SA (o $12 \%$ ).

W warunkach gospodarki rynkowej ważna jest dla przedsiębiorstwa stabilność kontaktów handlowych. Im bardziej produkty przedsiębiorstwa dostosowane są do indywidualnych wymagań klientów, tym bardziej wpływa to nie tylko na trwałość powiązań z odbiorcami, lecz również na lojalność odbiorców wobec dostawcy. Obniża się tym samym stopień niepewności producenta i ulega poprawie jego konkurencyjność, czego logiczną konsekwencją są długoterminowe kontrakty z odbiorcami zagranicznymi. Dane dotyczące udziału eksportu w przychodach ze sprzedaży dla 9 firm wskazują, że dynamika przychodów w pięciu przedsiębiorstwach jest wynikiem ,proeksportowego” profilu produkcji (tab. 4, ryc. 1-3). Ocena wpływu aktualnej sytuacji na rynku globalnym na kondycję ekonomiczną poszczególnych przedsiębiorstw będzie możliwa na podstawie danych za 2009 rok. Należy jednak zwrócić 
uwagę na kształtowanie się wyników finansowych firmy Volkswagen Poznań Sp. z o.o., której sprzedaż eksportowa w ostatnich latach wynosiła ok. 95\% (ryc. 3).

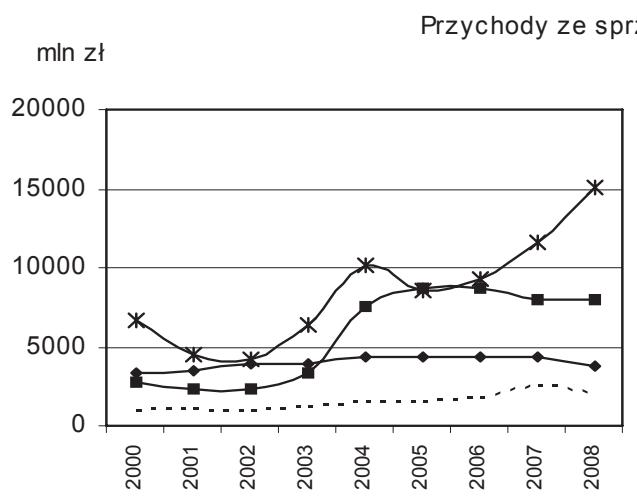

—_ Fiat Auto Poland SA, Bielsko-Biała

$\longrightarrow$ Volksw agen Poznań Sp. z o.o., Poznań

$\longrightarrow$ Volksw agen Motor Polska Sp. z o.o., Polkow ice

. . . . . . Volvo Polska Sp. z o.o., Wrocław

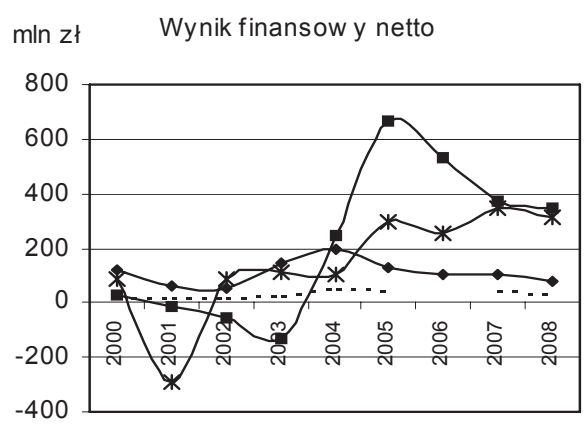

Zatrudnienie

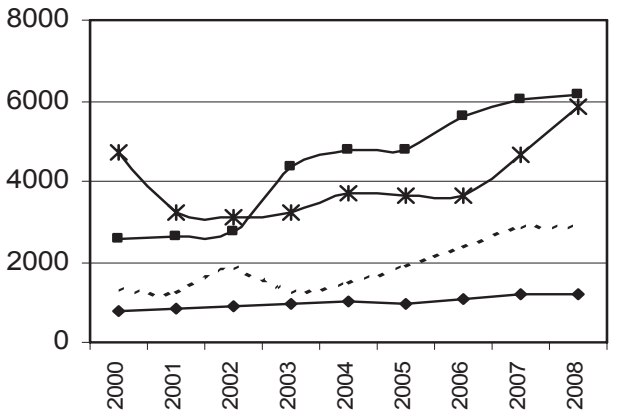

Ryc. 3. Rozwój przedsiębiorstw produkcyjnych wysokiej techniki (D34) w latach 2000-2008 w świetle podstawowych wskaźników ekonomicznych

Źródło: „Lista 500 największych firm Rzeczpospolitej” 2000-2008; opracowanie własne

Wyniki analizy dynamiki rozwoju 15 wielkich, pod względem przychodów ze sprzedaży, przedsiębiorstw produkcyjnych wysokiej techniki, należących do stałego podzbioru tych firm w latach 2000-2008 wskazują, że przedsiębiorstwa te potrafiły dostosować się do warunków nieprzewidywalności rynku i nasilenia konkurencji. Przyjęte za podstawę analizy i oceny efektywności rozwoju firm dane, które zawiera „Lista 500” największych przedsiębiorstw w Polsce w 2008 r., nie oddają jeszcze w pełni skutków światowego kryzysu. Wprawdzie efektywność funkcjonowania kilku przedsiębiorstw w ostatnich latach uwzględnionego okresu wyraźnie obniżyła się, można jednak stwierdzić, że analizowane przedsiębiorstwa będą potrafiły funkcjonować w warunkach wysokiej turbulencji otoczenia, kreującego zarówno szanse ${ }^{5}$, jak i szereg zagrożeń.

\footnotetext{
${ }^{5}$ Na przykład według Biura Inwestycji i Cykli Ekonomicznych wskaźnik informujący z wyprzedzeniem o przyszłych tendencjach w gospodarce wzrósł w grudniu br. po raz piąty z rzędu. Do wzrostu wartości wskaźnika
} 
Tab. 5. Udział eksportu w przychodach ze sprzedaży

w wybranych przedsiębiorstwach wysokiej techniki w latach 2000-2008 (\%)

\begin{tabular}{|l|r|r|r|}
\hline \multicolumn{1}{|c|}{ Nazwa przedsiębiorstwa } & 2000 & 2004 & 2008 \\
\hline GlaxoSmithKline Pharmaceuticals SA, Poznań & 6,5 & 29,0 & 64,0 \\
\hline Zakłady Azotowe Anwil SA, Włocławek & 37,7 & 0,7 & 46,5 \\
\hline Zakłady Azotowe Puławy SA, Puławy & 40,3 & 47,5 & 43,3 \\
\hline Zakłady Chemiczne Zachem SA, Bydgoszcz & 34,0 & 25,1 & 8,2 \\
\hline BSH Sprzęt Gospodarstwa Domowego Sp. z o.o., Warszawa & 41,8 & 78,4 & 73,0 \\
\hline Electrolux Poland Sp. z o.o., Warszawa & 0,7 & 38,1 & 67,6 \\
\hline Fiat Auto Poland SA, Bielsko-Biała & 51,7 & 81,6 & 85,9 \\
\hline Volkswagen Poznań Sp. z o.o, Poznań & 51,2 & 95,9 & 95,4 \\
\hline Volvo Polska Sp. z o.o., Wrocław & 49,8 & 52,5 & 45,0 \\
\hline
\end{tabular}

Źródło: „Lista 500 największych firm Rzeczpospolitej” 2000, 2004, 2008

Niezbędne jest rozumienie własnych procesów organizacyjnego uczenia się i zarządzania nimi w celu osiągnięcia korzyści oraz dysponowanie skutecznymi narzędziami dostosowania się do zmiennych warunków otoczenia. W takich warunkach dominującą rolę zdają się przejmować organizacje sieciowe. Dynamika nowej gospodarki w coraz większym stopniu polega bowiem na logice sieci, która zapewnia podmiotowi gospodarczemu przetrwanie i wzmocnienie pozycji konkurencyjnej dzięki wielostronnym relacjom współpracy. Funkcjonowanie przedsiębiorstw w świetle założeń modelu organizacji sieciowej oraz założeń innych modeli organizacji działających w warunkach wysokiej turbulencji otoczenia, a w efekcie identyfikacja źródeł osiągania i utrzymywania przez firmy lepszych wyników stanowi - jak zaznaczono na wstępie - przedmiot dalszych badań nad efektywnością rozwoju przedsiębiorstw produkcyjnych wysokiej techniki w Polsce. Inne problemy badawcze można sformułować następująco: 1) zachowania przestrzenne i strategie wybranych przedsiębiorstw wysokiej techniki (w tym firm reprezentujących sektor małych i średnich przedsiębiorstw), w szczególności w kontekście aktualnej sytuacji na rynku globalnym, 2) koncepcja przewag konkurencyjnych a funkcjonowanie przedsiębiorstw wysokiej techniki, 3) relacje między aktorami - uczestnikami gry ekonomicznej prowadzącymi działalność na obszarze Doliny Lotniczej oraz $\mathrm{w}$ odniesieniu do innych form przestrzennej organizacji produkcji, 4) rola przedsiębiorstw wysokiej techniki w tworzeniu popytu na pracę.

\section{Literatura}

Chojnicki Z., Czyż T., 2006, Aspekty regionalne gospodarki opartej na wiedzy w Polsce, Bogucki Wydawnictwo Naukowe, Poznań

Grudzewski W.M., Hejduk I.K., 2000, Kreowanie w przedsiębiorstwie organizacji inteligentnej, [w:] W.M. Grudzewski, I.K. Hejduk (red.), Przedsiębiorstwo przyszłości, Centrum Doradztwa i Informacji Difin sp. z o.o., Warszawa

w największym stopniu przyczyniła się poprawa wydajności pracy w sektorze przedsiębiorstw. Jest ona coraz wyższa przy względnie niewielkiej redukcji zatrudnienia. 
Grudzewski W.M., Hejduk I.K., 2008, Zarzqdzanie technologiami. Zaawansowane technologie $i$ wyzwanie ich komercjalizacji, Centrum Doradztwa i Informacji Difin sp. z o.o., Warszawa

Kobyłko G., Morawski M., 2006, Przedsiębiorstwo zorientowane na wiedzę, Centrum Doradztwa i Informacji Difin sp. z o.o., Warszawa

Krupski R. (red.), 2005, Zarzqdzanie przedsiębiorstwem w turbulencyjnym otoczeniu, PWE, Warszawa

Mikuła B., 2005, Procesy uczenia się organizacji jako zmiana zachowań organizacyjnych, [w:] A. Potocki (red.), Zachowania organizacyjne. Wybrane zagadnienia, Centrum Doradztwa i Informacji Difin sp. z o.o., Warszawa

Mikuła B., 2006, Organizacje oparte na wiedzy, Wydawnictwo Akademii Ekonomicznej w Krakowie, Kraków

Mikuła B., Pietruszka-Ortyl A., Potocki A. (red.), 2007, Podstawy zarzadzania przedsiębiorstwami w gospodarce opartej na wiedzy, Centrum Doradztwa i Informacji Difin sp. z o.o., Warszawa

Perechuda K., 2005, Dyfuzja wiedzy w przedsiębiorstwie sieciowym. Wizualizacja i kompozycja, Wydawnictwo Akademii Ekonomicznej im. Oskara Langego we Wrocławiu, Wrocław

Porter M., 2006, Przewaga konkurencyjna. Osiaganie i utrzymywanie lepszych wyników, Wydawnictwo Helion, Gliwice

Przybyszewski R., 2007, Kapitat ludzki w procesie ksztattowania gospodarki opartej na wiedzy, Centrum Doradztwa i Informacji Difin sp. z o.o., Warszawa

Senge P.M., 1998, Piqta dyscyplina. Teoria i praktyka organizacji uczacych się, Dom Wydawniczy ABC, Warszawa

Stryjakiewicz T., 1999, Adaptacja przestrzenna przemystu $w$ Polsce $w$ warunkach transformacji, Wydawnictwo Naukowe UAM, Poznań

Świdurska A., 2009, Ksztaltowanie się przemystu wysokiej techniki w Polsce, [w:] Z. Zioło, T. Rachwał (red.), Funkcje przemystu w ksztaltowaniu społeczeństwa informacyjnego, Prace Komisji Geografii Przemysłu PTG nr 13, Warszawa-Kraków

Welfe W. (red.), 2007, Gospodarka oparta na wiedzy, Polskie Wydawnictwo Ekonomiczne, Warszawa

Wieloński A., 2007, Zmiany strukturalne w przemyśle światowym na przełomie wieków, [w:] J. Lach, M. Borowiec, T. Rachwał (red.), Procesy transformacji spoleczno-ekonomicznych i przyrodniczych struktur przestrzennych, Wydawnictwo Naukowe AP, Kraków

Woroniecki J., 2003, Nowa gospodarka - ułuda czy rzeczywistość, Ekonomista, 5

Zioło Z., 2008, Procesy transformacji przemystowych ukladów przestrzennych na tle zmieniajqcego się otoczenia, [w:] Z. Zioło, T. Rachwał (red.), Procesy transformacji układów przestrzennych przemystu na tle zmieniajacego się otoczenia, Prace Komisji Geografii Przemysłu PTG nr 10, Warszawa-Kraków

Zioło Z., 2009, Rola przemystu w procesie kształtowania spoleczeństwa informacyjnego, [w:] Z. Zioło, T. Rachwał (red.), Funkcje przemystu w ksztaltowaniu społeczeństwa informacyjnego, Prace Komisji Geografii Przemysłu PTG nr 13, Warszawa-Kraków

\section{Efficiency of development of high-tech manufacturers in Poland}

The intensifying processes of integration and globalisation, uncertainty of action, and the dependence of the growth of an enterprise on the acquisition and use of knowledge in practically every aspect of its operation forces enterprises to take measures enhancing their performance and management. The contemporary enterprise, seeking to survive on the market and to tackle the constant changes in its milieu, must display a high level of flexibility and be able to modify its operation almost instantaneously.

From the perspective of world tendencies in the development of branches based on scientific and technological advances, Poland still displays a very low proportion of high-tech goods in its total sales. 
What is needed is a global approach to the catching-up process, which is facilitated, among other things, by the country's membership of the European Union and support from its funds.

The aim of this paper is to analyse and assess the efficiency of development of enterprises representing high-tech manufacturing in Poland. The basic source material employed is the data on firms that appeared on the list of 500 largest enterprises in Poland in the years 2000-2008.

Dr Anna Świdurska

Uniwersytet im. Adama Mickiewicza w Poznaniu

Instytut Geografii Społeczno-Ekonomicznej i Gospodarki Przestrzennej

e-mail: amswid@amu.edu.pl 